\title{
MODEL VALIDATION FOR ESTIMATING THE LEAF STOMATAL CONDUCTANCE IN CABERNET SAUVIGNON GRAPEVINES
}

\author{
Francisco Jara-Rojas $^{1}$, Samuel Ortega-Farías ${ }^{1 *}$, Héctor Valdés-Gómez ${ }^{1,2}$, Carlos Poblete ${ }^{1}$, \\ and Alejandro del Pozo ${ }^{3}$
}

\begin{abstract}
The coupled model of assimilation and stomatal conductance $\left(A-g_{s}\right)$ was evaluated to estimate leaf stomatal conductance of a drip-irrigated vineyard (Vitis vinifera L. cv. Cabernet Sauvignon) located in the Pencahue Valley ( $35^{\circ} 22^{\prime}$ S, $71^{\circ} 47^{\prime}$ W, 150 m.a.s.1.), Maule Region, Chile, during the 2003-2004 and the 2004-2005 growing seasons. Additionally, a calibration of the three parameters mesophyll conductance $\left(g_{m}\right)$, maximum specific humidity $\left(D_{\max }\right)$ and coupled factor $\left(f_{0}\right)$ was applied on vines growing in $35 \mathrm{~L}$ pots. An infrared gas analyzer was used to calibrate and evaluate the $A-g_{s}$ which allowed simultaneous measuring of the leaf net $\mathrm{CO}_{2}$ assimilation $(A)$ and stomatal conductance $\left(g_{s}\right)$ in 2 to $3 \mathrm{~h}$ intervals of time. The calibration indicated that the $g_{m}, D_{\max }$ and $f_{0}$ values were $1.15 \mathrm{~mm} \mathrm{~s}^{-1}, 52.31 \mathrm{~g}$ $\mathrm{kg}^{-1}$ and 0.90 , respectively. The validation in the drip-irrigated vineyard indicated that the $A$ - $g_{s}$ model was able to estimate the leaf stomatal conductance with a root mean square error (RMSE) of $0.05 \mathrm{~mol} \mathrm{~m}^{-2} \mathrm{~s}^{-1}$, model efficiency of $61 \%$ and agreement index of $90 \%$. The sensitivity analysis indicated that the $A-g_{s}$ model is affected considerably by the $g_{m}, D_{\max }$ and $f_{0}$ parameterization.
\end{abstract}

Key words: $A-g_{s}$ model, photosynthesis, mesophyll conductance, stem water potential, sensitivity analysis.

\section{INTRODUCTION}

Recent research indicates that it is possible to directly estimate water use or actual evapotranspiration (ET) of crops without using crop coefficients (Olioso et al., 2005; Ortega-Farias et al., 2004; 2007). Soil-vegetationatmosphere transfer (SVAT) models which require soil and climate information, as well as canopy characterization have been suggested for the ET estimation for diverse vegetal species (Olioso et al., 2005). Recent versions of SVAT models incorporate mathematical formulations of leaf stomatal conductance $\left(g_{s}\right)$ which regulate gas exchange $\left(\mathrm{CO}_{2}\right.$ and water) depending on atmospheric and soil water conditions. Among the many mathematical algorithms to estimate $g_{s}$ we can mention the Jarvis model (1976), which uses climate variables such as incident solar radiation, air temperature, relative humidity and soil

\footnotetext{
${ }^{1}$ Universidad de Talca, Facultad de Ciencias Agrarias, Centro de Investigación y Transferencia en Riego y Agroclimatología (CITRA), Casilla 747, Talca, Chile. ${ }^{*}$ Corresponding author (sortega@utalca.cl).

${ }^{2}$ Universidad de Talca, Facultad de Ingeniería, Escuela de Bioinformática, Casilla 747, Talca, Chile.

${ }^{3}$ Universidad de Talca, Facultad de Ciencias Agrarias, Departamento de Producción Agrícola, Casilla 747, Talca, Chile.

Received: 30 November 2007.

Accepted: 21 April 2008.
}

water content as its input. Collatz et al. (1991) proposed the use of the $\mathrm{CO}_{2}$ assimilation rate by Farquhar's model as an input parameter for estimating $g_{s}$ (Farquhar et al., 1980). This model formulation improved the estimation of $g_{s}$ because it included the non-linear interaction between transpiration and net $\mathrm{CO}_{2}$ assimilation. Jacobs (1994) proposed a coupled model of net assimilation $\left(A-g_{s}\right)$ to estimate $g_{s}$ in vine leaves. The $A-g_{s}$ model, unlike the one proposed by Jarvis, includes, a description of synergistic interactions among $\mathrm{CO}_{2}$ concentration, atmospheric variables and plant factors. Hence, the $A-g_{s}$ model gives an adequate response to the climatic changes produced by the systematic increase of $\mathrm{CO}_{2}$ in the atmosphere (Jacobs et al., 1996; Calvet et al., 1998b; Calvet, 2000; Calvet et al., 2004).

The $A-g_{s}$ model has been successfully applied to grapevines cv. Airen (Jacobs et al., 1996), discovering that this model was able to predict $g_{s}$ of vine leaves with an experimental error of $16 \%$ and a maximum deviation of $4.0 \mathrm{~mm} \mathrm{~s}^{-1}\left(0.16 \mathrm{~mol} \mathrm{~m} \mathrm{~m}^{-2} \mathrm{~s}^{-1}\right)$. On the other hand, studies by Calvet et al. (1998b) indicate that the $A-g_{s}$ model is sensitive to the parameterization of mesophyll conductance $\left(g_{m}\right)$ and internal $\mathrm{CO}_{2}$ concentration. In order to improve the performance of the $A-g_{s}$ model, Calvet $e t$ al. (2004) made a non-linear optimization of both $g_{m}$ and of the function that determines the $\mathrm{CO}_{2}$ concentration within 
the stomatal cavity. In practical terms, the quantification of $g_{s}$ is complex because temporal variability of stomatal conductance is considerable due to changes in environmental, soil and plant conditions (Baldocchi et al., 1991). For well-irrigated grapevines under field conditions, $g_{s}$ values could widely range from 0.6 to 0.1 $\mathrm{mol} \mathrm{m} \mathrm{s}^{-1}\left(15 \mathrm{~mm} \mathrm{~s}^{-1}\right.$ to $2.5 \mathrm{~mm} \mathrm{~s}^{-1}$, respectively) which is mainly affected by the cultivar (Pire and Ojeda, 1999).

Due to the scarcity of information about leaf stomatal conductance formulation, which can be used in SVAT models to directly estimate vine evapotranspiration, the objective of this research was to evaluate the $A$-g model in order to estimate the leaf stomatal conductance for a drip-irrigated Cabernet Sauvignon vineyard under semiarid conditions.

\section{Description of the $\boldsymbol{A - g _ { s }}$ model}

The estimation of leaf stomatal conductance can be expressed as (Jacobs et al., 1996):

$$
g_{s}=\frac{1.6 \mathrm{~A}}{C_{s}-C_{i}}
$$

where, $g_{s}$ is the conductance to water vapour flux through the stomata $\left(\mathrm{mol} \mathrm{m}^{-2} \mathrm{~s}^{-1}\right), 1.6$ represents the relationship between the $\mathrm{CO}_{2}$ diffusivity and water vapour in the air, $A$ is the net $\mathrm{CO}_{2}$ assimilation $\left(\mu \mathrm{mol} \mathrm{m}{ }^{-2} \mathrm{~s}^{-1}\right), C_{s}$ is the $\mathrm{CO}_{2}$ concentration on the surface adjacent to the leaf ( $\mu \mathrm{mol}$ $\mathrm{mol}^{-1}$ ) and $C_{i}$ is the $\mathrm{CO}_{2}$ concentration in the interior of the stomatal cavity $\left(\mu \mathrm{mol} \mathrm{mol}{ }^{-1}\right) . C_{i}$ can be calculated using Equations [2] and [3] (Jacobs et al., 1996; Calvet et al., 1998b):

$$
\begin{gathered}
C_{i}=f_{0}\left(1-\frac{D_{s}}{D_{\max }}\right) C_{s}+\left(1-f_{0}\left(1-\frac{D_{s}}{D_{\max }}\right)\right) \Gamma \\
D_{s}=\mathrm{q}^{*}\left(T_{s}\right)-\mathrm{q}_{s}
\end{gathered}
$$

where, $f_{0}$ is a coupled factor when $D_{s}=0 \mathrm{~g} \mathrm{~kg}^{-1}, D_{s}$ is the specific humidity deficit between the sub-stomatal cavity and the atmosphere $\left(\mathrm{g} \mathrm{kg}^{-1}\right), D_{\max }$ is the maximum specific humidity at saturation $\left(\mathrm{g} \mathrm{kg}^{-1}\right), \mathrm{q}_{s}$ is the specific humidity in the atmosphere near the leaf surface $\left(\mathrm{g} \mathrm{kg}^{-1}\right)$, $\mathrm{q}^{*}\left(T_{s}\right)$ is the specific humidity in saturation $\left(\mathrm{g} \mathrm{kg}^{-1}\right)$ at the leaf temperature $T_{s}\left({ }^{\circ} \mathrm{C}\right)$ and $\Gamma$ is $\mathrm{CO}_{2}$ compensation point $\left(\mu \mathrm{mol} \mathrm{mol}^{-1}\right)$. In this case it is assumed that the stomatal cavity, where the gaseous exchange with the atmosphere takes place, is permanently saturated.

Net $\mathrm{CO}_{2}$ assimilation $\left(\mu \mathrm{mol} \mathrm{m} \mathrm{m}^{-2} \mathrm{~s}^{-1}\right)$ can be estimated according to the saturation equation (Calvet et al., 1998b):

$$
A=\left(\left(A_{m}+R_{d}\right)\left[1-\exp \left(-\varepsilon I_{a} F_{c} /\left(A_{m}+R_{d}\right)\right)\right]-R_{d}\right) F_{c,}
$$

where, $A_{m}$ is net assimilation as a function of $\mathrm{CO}_{2}$ $\left(\mathrm{mg} \mathrm{m}^{-2} \mathrm{~s}^{-1}\right), R_{d}$ is the leaf respiration $\left(\mathrm{mg} \mathrm{m}^{-2} \mathrm{~s}^{-1}\right), I_{a}$ is the photosynthetically active radiation (PAR) that reaches the leaf $\left(\mu \mathrm{mol} \mathrm{m} \mathrm{m}^{-2} \mathrm{~s}^{-1}\right), \varepsilon$ is the initial quantum use efficiency $\left(\mathrm{mg} \mathrm{CO} \mathrm{CO}_{2}[\mathrm{~J} \mathrm{PAR}]^{-1}\right), F_{c}$ is the conversion factor between the PAR that reaches the leaf and its associated energy $\left(F_{c}=0.22 \mathrm{~J} \mathrm{PAR} \mu \mathrm{mol}^{-1}\right.$, in accordance to the relation of 1 mol of photons $\equiv 0.22$ MJ PAR [Thornley and Johnson, 2000]), and $F_{\mathrm{CO} 2}$ is the conversion factor between mass unit and molar unit of $\mathrm{CO}_{2}\left(22.727 \mu \mathrm{mol} \mathrm{CO}_{2}\left[\mathrm{~g} \mathrm{CO}_{2}\right]^{-1}\right)$.

The net assimilation as a function of $\mathrm{CO}_{2}\left(\mathrm{mg} \mathrm{m}^{-2} \mathrm{~s}^{-1}\right)$ can be expressed through the following equation (Calvet et al., 2004):

$$
A_{m}=A_{m \max }\left[1-\exp \left(-0.001 g_{m}\left(C_{i}-\Gamma\right) \Phi_{c o} / A_{m \max }\right)\right]
$$

where, $A_{m, \max }$ is the maximum net $\mathrm{CO}_{2}$ assimilation (mg $\left.\mathrm{m}^{-2} \mathrm{~s}^{-1}\right), g_{m}$ is mesophyll conductance $\left(\mathrm{mm} \mathrm{s}^{-1}\right)$ and $\Phi_{\mathrm{CO}_{2}}$ is a conversion factor $\left(\Phi_{\mathrm{CO}_{2}}=1.799 \mathrm{mg} \mathrm{CO}_{2} \mathrm{~m}^{-3}\right.$ at $25^{\circ} \mathrm{C}$ and $1 \mathrm{~atm})$.

The leaf respiration, $R_{d}\left(\mathrm{mg} \mathrm{m}^{-2} \mathrm{~s}^{-1}\right)$, is calculated as (Calvet et al., 2004):

$$
R_{d}=A_{m} / 9
$$

The initial quantum use efficiency $\left(\mathrm{mg} \mathrm{CO}_{2}[\mathrm{~J} \mathrm{PAR}]^{-1}\right)$ is defined as (Jacobs et al., 1996; Calvet et al., 1998b; 2004):

$$
\varepsilon=\varepsilon_{0} \frac{C_{i}-\Gamma}{C_{i}+2 \Gamma}
$$

where, $\varepsilon_{0}$ is the maximum quantum use efficiency (mg CO${ }_{2}\left[\mathrm{~J} \mathrm{PAR}^{-1}\right.$ ).

The values of $\Gamma, A_{m, \max }$ and $g_{m}$ are adjusted according to the leaf temperature $\left(T_{s}\right)$ by the functions $Q_{10}$ as shown in Equations [8] and [9] (Jacobs et al., 1996; Calvet et al., 1998b):

$$
\begin{gathered}
X\left(T_{s}\right)=X(@ 25) Q_{10}^{\left(s_{-}-25\right) 10} \\
X\left(T_{s}\right)=\frac{X(@ 25) Q_{10}^{\left(T_{1}-25\right) 10}}{\left[1+\exp \left(0.3\left(T_{1}-T_{s}\right)\right)\right]\left[1+\exp \left(0.3\left(T_{s}-T_{2}\right)\right)\right]}
\end{gathered}
$$

where, $X(@ 25)$ is the value of the parameters at $25{ }^{\circ} \mathrm{C}$ (Table 1), $Q_{10}$ is a relationship for the effect of temperature on a process such that the process rate increases by the same multiple for every $10{ }^{\circ} \mathrm{C}$ rise in temperature. $T_{s}$ is the leaf temperature $\left({ }^{\circ} \mathrm{C}\right), T_{1}$ is the inferior reference temperature $\left({ }^{\circ} \mathrm{C}\right)$ and $T_{2}$ is the superior reference temperature $\left({ }^{\circ} \mathrm{C}\right)$. The temperature adjustment for $\Gamma$ was performed using Equation [8], and for $A_{m, \max }$ and $g_{m}$ was performed using Equation [9]. The summary of the input parameters is shown in Table 1 .

\section{MATERIALS AND METHODS}

With the purpose of evaluating the estimations of $g_{s}$ using the $A-g_{s}$ model, an experiment was carried out 
Table 1. Input parameters used in the coupled assimilation-stomatal conductance (A-g $)$ model for vines.

\begin{tabular}{|c|c|c|c|c|c|c|}
\hline Parameter & Adjusted by & $\mathrm{X}(@ 25)^{1}$ & $\mathbf{A} \mathbf{Q}_{10}$ & $\mathrm{~T}_{1}\left({ }^{\circ} \mathrm{C}\right)$ & $\mathrm{T}_{2}\left({ }^{\circ} \mathrm{C}\right)$ & Source \\
\hline$\varepsilon_{0}, \mathrm{mg} \mathrm{CO}_{2}[\mathrm{~J} \mathrm{PAR}]^{-1}$ & - & 0.017 & - & - & - & $\begin{array}{l}\text { Farquhar et al., 1980; Jacobs } \\
\text { et al., 1996; Calvet et al., 1998b }\end{array}$ \\
\hline$f_{0}$, dimensionless & - & 0.916 & - & - & - & Jacobs et al., 1996 \\
\hline$\Gamma, \mu \mathrm{mol} \mathrm{mol}{ }^{-1}$ & Equation [8] & 45.0 & 1.5 & - & - & $\begin{array}{l}\text { Jacobs et al., 1996; Calvet et al., } \\
\text { 1998b }\end{array}$ \\
\hline$g_{m}, \mathrm{~mm} \mathrm{~s}^{-1}$ & Equation [9] & 2.0 & 2.0 & 0 & 42 & $\begin{array}{l}\text { Jacobs et al., 1996; Candolfi- } \\
\text { Vasconcelos y Koblet, 1991; } \\
\text { Moutinho-Pereira et al., } 2004\end{array}$ \\
\hline$A_{m, \max }, \mathrm{mg} \mathrm{m}^{-2} \mathrm{~s}^{-1}$ & Equation [9] & 2.2 & 2.0 & 15 & 42 & $\begin{array}{l}\text { Jacobs et al., 1996; Calvet et al., } \\
\text { 1998b }\end{array}$ \\
\hline$D_{\max }, \mathrm{g} \mathrm{kg}^{-1}$ & - & 58.2 & - & - & - & Jacobs et al., 1996 \\
\hline
\end{tabular}

${ }^{1}$ Parameter value at $25^{\circ} \mathrm{C}$. $\varepsilon_{0}$ is the maximum quantum use efficiency, $f_{0}$ is a coupled factor when the deficit of specific humidity is equal to $0, \Gamma$ is the $\mathrm{CO}_{2}$ compensation point, $A_{m, \max }$ is maximum net assimilation, $g_{m}$ is mesophyll conductance; $D_{\max }$ is maximum specific humidity; and $Q_{10}$ : a relationship for the effect of temperature on a process.

during the 2003-2004 and 2004-2005 growing seasons. Data were registered between January and March in a drip-irrigated commercial vineyard with 11-year-old Cabernet Sauvignon vines without grafting. The vineyard is located in the Pencahue Valley ( $35^{\circ} 22^{\prime} \mathrm{S} ; 71^{\circ} 47^{\prime} \mathrm{W} ; 150$ m.a.s.1.), Maule Region, Chile. The vine spacing was 3.0 $\mathrm{m}$ between rows $\mathrm{x} 1.2 \mathrm{~m}$ within rows, with plants trained on a vertical shoot-positioned system and bilateral-cordon pruned $\left(20\right.$ buds $\left.\mathrm{m}^{-1}\right)$ with vine rows oriented $18^{\circ} \mathrm{W}$ in relation to the $\mathrm{N}-\mathrm{S}$ axis.

The climate of the area is semi-arid Mediterranean with maximum and minimum average daily temperature of 32.6 and $5.5^{\circ} \mathrm{C}$, respectively. The annual average precipitation reaches $709 \mathrm{~mm}$, and the water deficit reaches $863 \mathrm{~mm}$, with a dry period of 7 months. The details of the climatic conditions during the measurement period are summarized in Figure 1. The soil in the vineyard is classified as Cunculén Series (Aquic Palexeralfs) with a sandy loam texture and an effective root depth of $60 \mathrm{~cm}$. At this point, the bulk density, field capacity, wilting point and available water are at $1.48 \mathrm{~g} \mathrm{~cm}^{-3}, 30 \%(180 \mathrm{~mm}), 11 \%(66 \mathrm{~mm})$ and $19 \%(114 \mathrm{~mm})$, respectively. The irrigation schedule was determined according to the daily ET values of the vineyard (Acevedo et al., 2005) and the water supply was made using $3.5 \mathrm{~L} \mathrm{~h}^{-1}$ drippers spaced at $1.2 \mathrm{~m}$.

An automatic meteorological station(Adcon Telemetry, model A730, Klosterneuburg, Austria) was installed in the vineyard to measure air temperature, relative humidity, solar radiation, precipitation, wind velocity and direction at $30 \mathrm{~min}$ intervals. The sensors were located at $2.5 \mathrm{~m}$ above the ground, with the exception of the temperature and relative humidity sensors that were located within the canopy at $1.5 \mathrm{~m}$ above ground, and the pluviometer was located at $3 \mathrm{~m}$ above ground.

An infrared gas analyzer (ADC BioScientific Ltd., model LCi, Hoddesdon, UK) was used to measure the daytime variation of photosynthetically active radiation (PAR), stomatal conductance $\left(g_{s}\right)$, transpiration $(E)$ and net $\mathrm{CO}_{2}$ assimilation $(A)$ from 30 healthy leaves as well as other variables related to gas exchange $\left(C_{i}, C_{s}, T_{s}\right.$ and $\left.D_{s}\right)$. The measurements of gas exchange were made between 08:00 and 20:00 h at regular intervals (every 2 or $3 \mathrm{~h}$ ) during the both growing seasons. At the same time, the midday stem water potential $\left(\Psi_{\mathrm{x}}\right)$ was measured using a pressure chamber (PMS Instrument Co., model 600, Corvallis, Oregon, USA) (Choné et al., 2001). In this case, six full expanded leaves were encased in plastic bags and then wrapped in aluminium foil at least $2 \mathrm{~h}$ before taking the measurements, these were taken between 13:00 and 14:00 h (Ortega-Farías et al., 2004). For measurements of each gas exchange and plant water status leaves were chosen from the middle zone of the canopy and had east and west sunlight exposure, respectively (Jacobs et al., 1996; Moutinho-Pereira et al., 2004).

The database of gas exchange was submitted to an exploratory data analysis to determine the existence of measurement errors. Data were removed from the dataset when: (i) temperature within the infrared gas analyzer chamber was over $42{ }^{\circ} \mathrm{C}$ (Jacobs, 1994) and (ii) when they exceed a reference value of mean \pm 2 standard deviations.

Prior to the evaluation of the model, values of $g_{m}, D_{\max }$ and $f_{0}$ were calibrated with 6-year-old vines growing in $35 \mathrm{~L}$ pots. In order to achieve this objective, an experiment was conducted at the 'Panguilemo' Experimental Station ( $36^{\circ} 26^{\prime}$ S, $71^{\circ} 41^{\prime}$ W; 110 m.a.s.l.) belonging to Universidad de Talca, Maule Region, during the 2004-2005 growing season. Sixteen own-rooted vines (Vitis vinifera L., cv. Cabernet Sauvignon) were used in the experiment and four vines were randomly selected for measuring gas exchange. A commercial organic soil was 


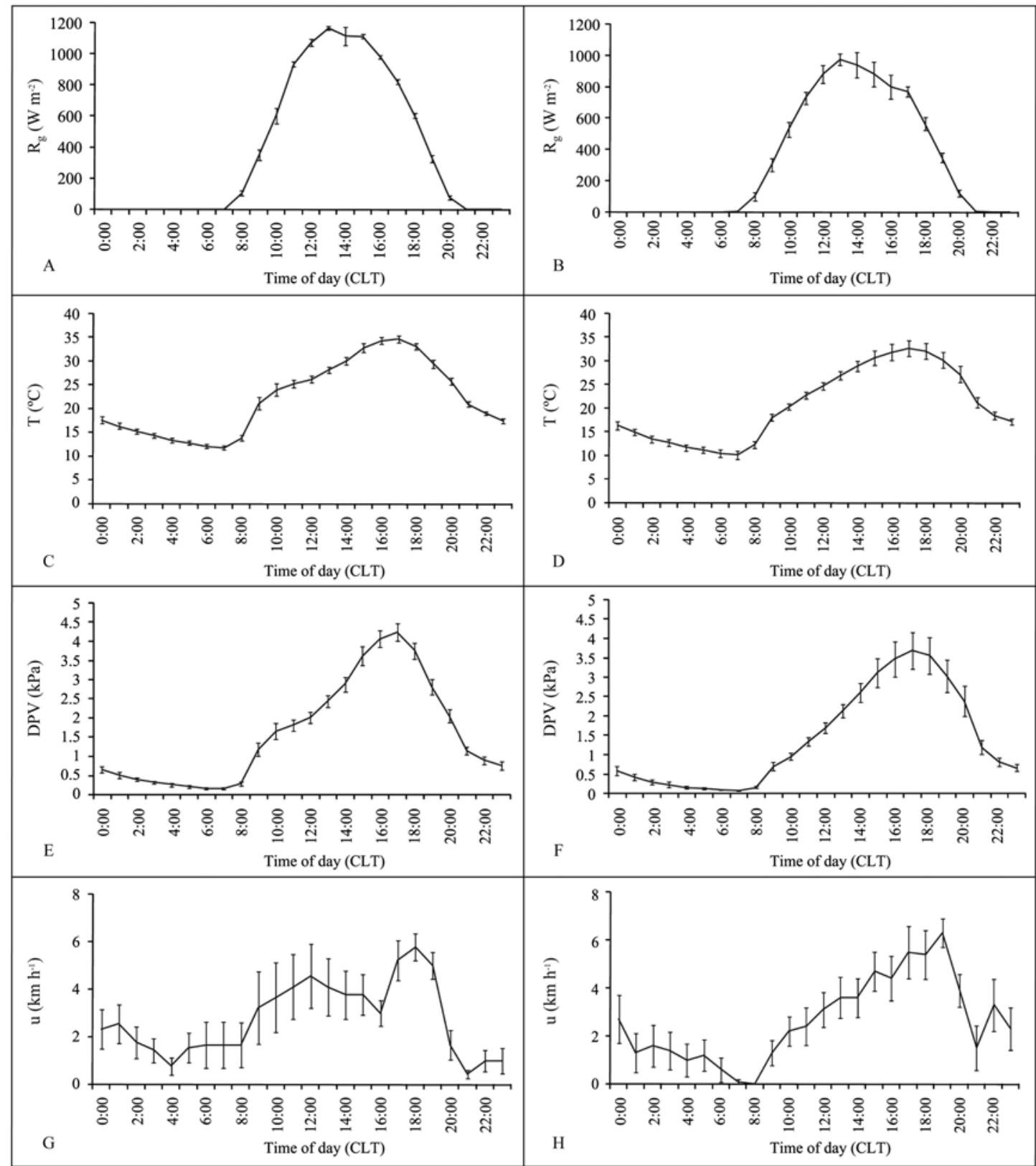

Figure 1. Micrometeorological characterization of experimental area in Pencahue Valley during the 2003-2004 (left) and 2004-2005 (right) growing seasons. $A$ and $B$ : solar radiation $\left(R_{g}, W ~ m^{-2}\right) ; C$ and $D$ : temperature $\left(T,{ }^{\circ} C\right) ; E$ and $F$ : vapour pressure deficit (DPV, $\mathrm{kPa})$; $\mathrm{G}$ and $\mathrm{H}$ : wind speed $\left(\mathrm{u}, \mathrm{km} \mathrm{h}^{-1}\right)$. Each point represents an average of at least 5 days of measurements. Vertical bars represent mean standard error. CLT: Chilean local standard time.

used as pot substrate. The bulk density, field capacity and wilting point of the substrate were $0.6 \mathrm{~g} \mathrm{~cm}^{-3}, 37 \%(167$ $\mathrm{mm})$ and $12 \%(54 \mathrm{~mm})$, respectively. The 16 pots were distributed outdoors in rows with N-S orientation and spaced at $3 \times 1 \mathrm{~m}$. Each pot was covered with white plastic to minimize soil evaporation and to lessen heating from solar exposure. The vines were trained on a vertical shootpositioned system and were pruned in bilateral cordons. The evaluations were carried out post-setting from the end of November to February. Due to the crop load variability among the vines observed in previous seasons, all the clusters were reaped before berry set. The irrigation scheduling was determined using the same criteria used at the field experiment (Acevedo et al., 2005). Data of the gas exchange, stem water potential and climatic variables were measured using the same equipment and frequency as described in the field experiment. 
The calibration of $g_{m}, D_{\max }$ and $f_{0}$ was performed using a non-linear optimization method that consisted of minimizing the root mean square error (RMSE) between the observed and the estimated values of net $\mathrm{CO}_{2}$ assimilation (Calvet et al., 1998a; 1998b; 2004; Calvet, 2000). Using the calibrated values of $g_{m}, D_{\max }$ and $f_{0}$, and the constant parameters from literature (Table 1), the performance of $A-g_{s}$ model was evaluated with data measured from the drip-irrigated Cabernet Sauvignon vineyard located in the Pencahue Valley. The evaluation of the model was done using the RMSE, agreement index (AI) and model efficiency (EF) (Willmott, 1982; Mayer and Butler, 1993) between the observed and the estimated values of $A$ and $g_{s}$. Finally, a sensitivity analysis of the $A-g_{s}$ model was carried out varying the values of $\varepsilon_{0}, f_{0}, \Gamma, g_{m}, A_{m, \max }$ and $D_{\max }$ by \pm $30 \%$ to detect the critical parameters of the model.

\section{RESULTS AND DISCUSSION}

\section{Environmental conditions and vine water status}

The maximum and minimum air temperatures were 37.6 and $9{ }^{\circ} \mathrm{C}$, respectively, in the 2003-2004 growing season, and 38.0 and $5.9^{\circ} \mathrm{C}$, in the 2004-2005 growing season. For both of these, the minimum temperature occurred between 07:00 and 08:00 $\mathrm{h}$ and the maximum temperature was reached between 16:00 and 17:00 h (Figure 1C and 1D). The maximum vapour pressure deficit ranged around $4.5 \mathrm{kPa}$ in both seasons and was registered in the same hours the maximum temperatures were observed. Cloud cover during the days in which measurements were taken was less than $10 \%$, which provided an adequate sunlight exposure to the plants (Figure 1A and 1B). Total rainfall from budbreak to harvest was 120 and $131 \mathrm{~mm}$ for the 2003-2004 and 2004-2005 growing seasons, respectively, where over $80 \%$ of the total rainfall was concentrated in spring.

The measured values of midday stem water potential in both study seasons ranged between -0.5 and $-1.0 \mathrm{MPa}$ with the lowest values of $\Psi_{\mathrm{x}}$ being observed between veraison and harvest in the 2004-2005 growing season (Figure 2). These $\Psi_{x}$ values indicate that vines were not subject to significant water stress during both study periods (Ortega-Farias et al., 2007).

\section{Model evaluation and sensitivity analysis}

The non-linear optimization made with the data obtained from the potted vines indicated that the values of $g_{m}, D_{\max }$ and $f_{0}$ were $1.15 \mathrm{~mm} \mathrm{~s}^{-1}, 52.31 \mathrm{~g} \mathrm{~kg}^{-1}$ and 0.90 , respectively. These were in the range of values reported by Calvet et al. (2004) for fruit trees, where $g_{m}$ varied between 0.21 and $8.5 \mathrm{~mm} \mathrm{~s}^{-1}, D_{\max }$ between 20 and $300 \mathrm{~g} \mathrm{~kg}^{-1}$ and $f_{0}$ between 0.434 and 0.90 . These results differed from those found by Jacobs (1994) and Jacobs et al. (1996) who indicated values for $g_{m}, D_{\max }$ and $f_{0}$ in Airen vines equivalent to $2.0 \mathrm{~mm} \mathrm{~s}^{-1}, 58.2 \mathrm{~g} \mathrm{~kg}^{-1}$ and 0.92 , respectively. Likewise, $g_{m}$ is different from the value of $2.5 \mathrm{~mm} \mathrm{~s}^{-1}$ obtained by Düring (2003) for Riesling vines. This difference in the values of $g_{m}$ could be associated with specific characteristics of each cultivar as it was pointed out by Patakas et al. (2003). These researchers studied the photosynthetic rates of three vine cultivars (Syrah, Athiri, and Asyrtiko) during different phenological stages and observed that the differences among them could be explained by, among other factors: i) their inherent anatomical differences (thickness of the spongy and palisade parenchyma, fraction of inter-cellular space), ii) the age of the leaf, and iii) the differences in the resistance of the liquid- $\mathrm{CO}_{2}$ phase of the leaves. From this same study, it can be inferred that the value of the mesophyll conductance, corresponding to the stem water potential measured in our study was near $0.9 \mathrm{~mm} \mathrm{~s}^{-1}$, which is close to the optimized value for cv. Cabernet Sauvignon. The prior information indicates that the cultivar, plant water status and leaf age are factors to consider when studying gas exchange over time. In a global study of 32 databases of agricultural, forestry and ornamental plants, Calvet et al. (2004) proposed that there is a relationship between $g_{m}$ and $f_{0}$, that would be stable among species under study. This relation provides a value of $g_{m}=1.0 \mathrm{~mm} \mathrm{~s}^{-1}$ for $f_{0}$ values close to 0.9 , like those obtained in the present study.

The field comparison indicated that $A$ and $g_{s}$ models presented RMSE values of $2.28 \mu \mathrm{mol} \mathrm{m}^{-2} \mathrm{~s}^{-1}$ and 0.05 mol m$~_{-2} \mathrm{~s}^{-1}$ for net $\mathrm{CO}_{2}$ assimilation and $g_{s}$, respectively (Table 2). These values are similar to those observed in pine trees by Calvet et al. (2004), who indicated that the models were capable of predicting net $\mathrm{CO}_{2}$ assimilation

Table 2. Statistical analysis for the leaf net assimilation and stomatal conductance models (cv. Cabernet Sauvignon).

\begin{tabular}{lccc}
\hline Variable & RMSE & IA & EF \\
\hline${\text { Net } \mathrm{CO}_{2} \text { assimilation }}^{(\mathrm{x})}, \mu \mathrm{mol} \mathrm{m} \mathrm{m}^{-2} \mathrm{~s}^{-1}$ & 2.28 & 0.91 & 0.63 \\
${\text { Stomatal conductance of water vapour, } \mathrm{mol} \mathrm{m}{ }^{-2} \mathrm{~s}^{-1}}$ & 0.05 & 0.90 & 0.61 \\
\hline
\end{tabular}

${ }^{(\mathrm{x})} g_{m}=1.15 \mathrm{~mm} \mathrm{~s}^{-1} ; \mathrm{D}_{\max }=52.31 \mathrm{~g} \mathrm{~kg}^{-1} ;$ and $f_{0}=0.90 . g_{m}$ is mesophyll conductance; $D_{\max }$ is the maximum specific humidity; and $f_{0}$ is a coupled factor when deficit of specific humidity is equal to 0 .

RMSE: root mean square error $\left((\mu) \mathrm{mol} \mathrm{m}^{-2} \mathrm{~s}^{-1}\right.$, as corresponds); AI: agreement index (dimensionless; IA $=1$ represents a perfect prediction of the model); $\mathrm{EF}$ : efficiency of the model (dimensionless; $\mathrm{EF}=1$ represents maximum efficiency, $\mathrm{EF}<0$ represents that the model is inadequate) 


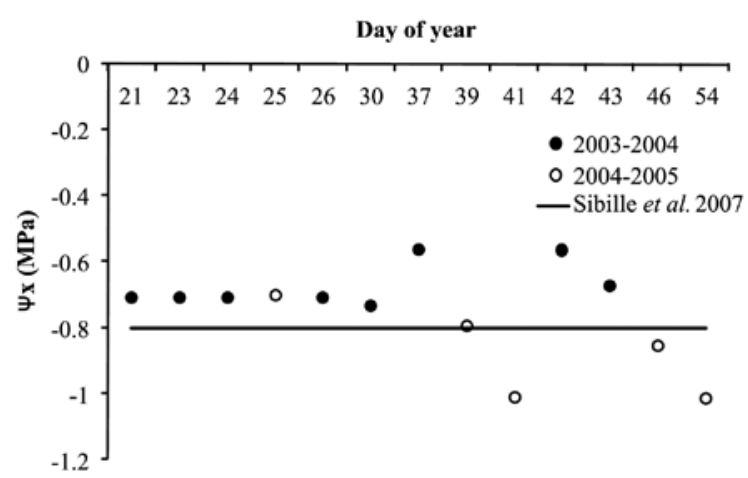

Figure 2. Evolution of midday stem water potential $(\Psi x)$ during the experiment (Cabernet Sauvignon vines, 2003-2004 and 2004-2005 growing seasons, Pencahue, Maule Region, Chile).

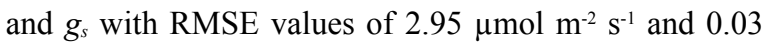
mol m $\mathrm{m}^{-2} \mathrm{~s}^{-1}$, respectively. In this study, the model efficiency values were greater than $60 \%$ and the agreement index exceeded $90 \%$, which indicates a good performance of the $A-g_{s}$ model (Garnier et al., 2001). Figure 3 shows that estimations of net $\mathrm{CO}_{2}$ assimilation showed more variability around the 1:1 line than those of $g_{s}$, and the values of $g_{s}$ were underestimated for observed values of $g_{s}$ greater than $0.3 \mathrm{~mol} \mathrm{~m}^{-2} \mathrm{~s}^{-1}$.

The sensitivity analysis suggested that $A-g_{s}$ model is highly sensitive to errors in the parameterization of $g_{m}$ $D_{\max }$ and $f_{0}$ (Table 3 ). In this case, an error of $\pm 30 \%$ in the values of $g_{m} D_{\operatorname{maxy}}$ and $f_{0}$ would respectively produce variations in the simulation of $g_{s}$ between 17.9 and $21.5 \%, 33.3$ and $-40.1 \%$ and -241 and $-51 \%$, respectively. On the other hand, the model presented a low sensitivity to the parameterization of $A_{m, \max }, \Gamma$ and $\varepsilon_{0}$. These results positively confirm the choice made of calibrating $g_{m}, D_{\max }$ and $f_{0}$, which had been suggested by Calvet et al. (2004) to achieve a better performance of the $A-g_{s}$ model to simulate the leaf stomatal conductance.

\section{Daytime variation of stomatal conductance and net $\mathrm{CO}_{2}$ assimilation}

For the two study periods, the Figures 4 and 5 indicate that estimated and observed values of $A$ and $g_{s}$ were close from 08:00 h to 18:00 h. The measured values of $g_{s}$ and net $\mathrm{CO}_{2}$ assimilation of leaves are in the ranges reported by literature for a great number of vine cultivars (Jacobs et al., 1996; Pire and Ojeda, 1999; Patakas et al., 2003; Düring, 2003; Singsaas et al., 2003). However, not many studies indicate the effect of leaf position or leaf orientation inside the canopy on the magnitude of the measurements. Related to this, Jacobs et al. (1996) reported for grapevines (cv. Airen), maximum values of $g_{s}$ equal to $0.29 \mathrm{~mol} \mathrm{~m}^{-2} \mathrm{~s}^{-1}$ for the shaded side of the canopy and $0.33 \mathrm{~mol} \mathrm{~m}^{-2} \mathrm{~s}^{-1}$ for the sunlit side. Maximum assimilation values were $5.7 \mu \mathrm{mol} \mathrm{m}^{-2} \mathrm{~s}^{-1}$ for the shaded side of the canopy and $15.6 \mu \mathrm{mol} \mathrm{m} \mathrm{m}^{-2} \mathrm{~s}^{-1}$ for the sunlit side. These values are very close to those measured in our research for $\mathrm{cv}$. Cabernet Sauvignon.

Good daytime performance to estimate leaf stomatal conductance to water vapour suggests that $A-g_{s}$ model could be used in the mathematical algorithm of SVAT

Table 3. Sensitivity analysis for net assimilation and stomatal conductance models of vine leaves (cv. Cabernet Sauvignon).

\begin{tabular}{|c|c|c|c|c|c|c|}
\hline \multirow{2}{*}{$\begin{array}{l}\text { Parameter and } \\
\text { variation level (\%) }\end{array}$} & \multicolumn{3}{|c|}{ Net assimilation ${ }^{(x)}\left(\mu \mathrm{mol} \mathrm{m} \mathrm{m}^{-2} \mathrm{~s}^{-1}\right)$} & \multicolumn{3}{|c|}{ Stomatal conductance $\left(\mathrm{mol} \mathrm{m}^{-2} \mathrm{~s}^{-1}\right)$} \\
\hline & $\mathbf{E F}$ & RMSE & Variation & EF & RMSE & IN \\
\hline & & & $\%$ & & & $\%$ \\
\hline$\varepsilon_{0}+30$ & 0.58 & 2.43 & 7.9 & 0.65 & 0.043 & 7.5 \\
\hline$\varepsilon_{0}-30$ & 0.66 & 2.19 & -11.4 & 0.52 & 0.051 & -11.0 \\
\hline $\mathrm{f}_{0}+30$ & 0.09 & 3.59 & 23.1 & N/A & 6.290 & -241.0 \\
\hline $\mathrm{f}_{0}-30$ & 0.67 & 2.17 & -25.7 & -0.14 & 0.078 & -50.5 \\
\hline$\Gamma+30$ & 0.70 & 2.07 & -10.8 & 0.58 & 0.047 & -3.1 \\
\hline$\Gamma-30$ & 0.49 & 2.68 & 11.8 & 0.63 & 0.044 & 3.4 \\
\hline $\mathrm{g}_{\mathrm{m}}+30$ & 0.17 & 3.42 & 17.6 & 0.43 & 0.055 & 17.9 \\
\hline$g_{m}-30$ & 0.68 & 2.13 & -21.3 & 0.48 & 0.053 & -21.5 \\
\hline $\mathrm{A}_{\mathrm{m}, \max }+30$ & 0.62 & 2.33 & 1.1 & 0.60 & 0.046 & 1.3 \\
\hline$A_{m, \max }-30$ & 0.66 & 2.19 & -2.1 & 0.61 & 0.045 & -2.3 \\
\hline $\mathrm{D}_{\max }+30$ & 0.36 & 3.01 & 13.4 & 0.36 & 0.059 & 33.3 \\
\hline $\mathrm{D}_{\max }-30$ & 0.61 & 2.35 & -27.6 & 0.22 & 0.065 & -40.1 \\
\hline
\end{tabular}

(x) $g_{m}=1.15 \mathrm{~mm} \mathrm{~s}^{-1} ; \mathrm{D}_{\max }=52.31 \mathrm{~g} \mathrm{~kg}^{-1}$; and $f_{0}=0.90 . g_{m}$ is mesophyll conductance; $D_{\max }$ is the maximum specific humidity; and $f_{0}$ is a coupled factor when deficit of specific humidity is equal to 0 .

EF: efficiency of the model (dimensionless; $\mathrm{EF}=1$ represents maximum efficiency, $\mathrm{EF}<0$ represents that the model is inadequate); RMSE: root mean square error $\left((\mu) \mathrm{mol} \mathrm{m}^{-2} \mathrm{~s}^{-1}\right.$, as corresponds). 

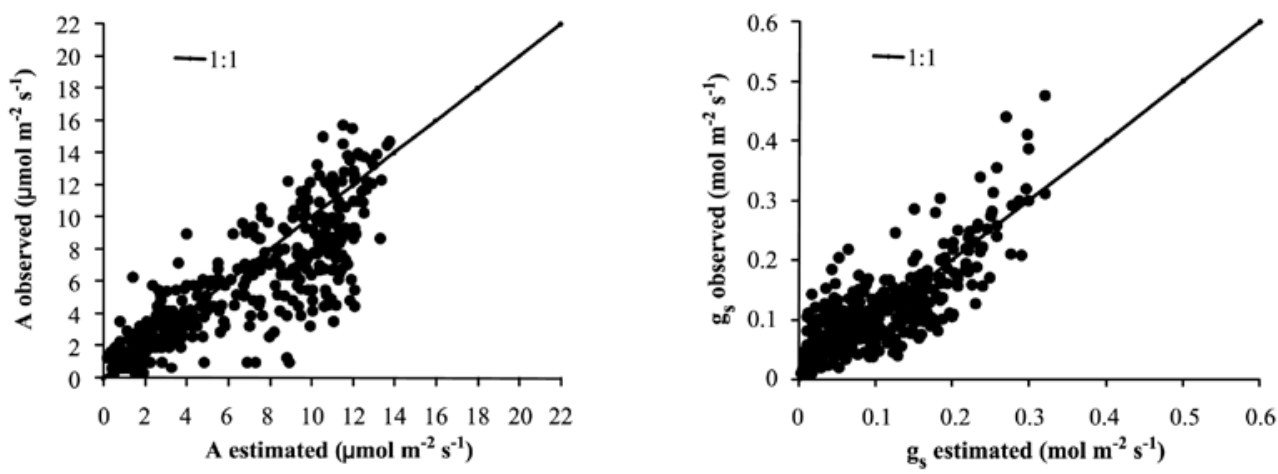

Figure 3. Comparison between observed and estimated values of net assimilation $(A)$ and stomatal conductance $\left(g_{s}\right)$

Cabernet Sauvignon grapevines, 2003-2004 and 2004-2005 growing seasons. Pencahue, Maule Region, Chile.

models to directly estimate grapevine water use. This allows for studying the mid and long-term impact of global climatic change in the vine water requirement, which is very important to optimize the water application at farm and regional level.

\section{CONCLUSIONS}

The results of this study indicate that the $A$-g model was able to estimate stomatal conductance of vine leaves (cv. Cabernet Sauvignon) with a root mean square error (RMSE) of $0.05 \mathrm{~mol} \mathrm{~m}^{-2} \mathrm{~s}^{-1}$, model efficiency of $61 \%$ and an agreement index of $90 \%$. The model reproduces, in general terms, the daytime variation of stomatal conductance in both sides of the vineyard canopy (sunlit and shaded side). The calibration indicated that values of $g_{m}, D_{\max }$ and $f_{0}$ were $1.15 \mathrm{~mm} \mathrm{~s}^{-1}, 52.31 \mathrm{~g} \mathrm{~kg}^{-1}$ and 0.90 , respectively. Also, the sensitivity analysis suggested that the $A-g_{s}$ model is considerably affected by the errors in the parameterization of $g_{m}, D_{\max }$ and $f_{0}$.

\section{ACKNOWLEDGEMENTS}

The research study leading to this report was supported by the Chilean projects FONDECYT N ${ }^{\circ} 1030314$ and Bicentenario PSD-86/2006.

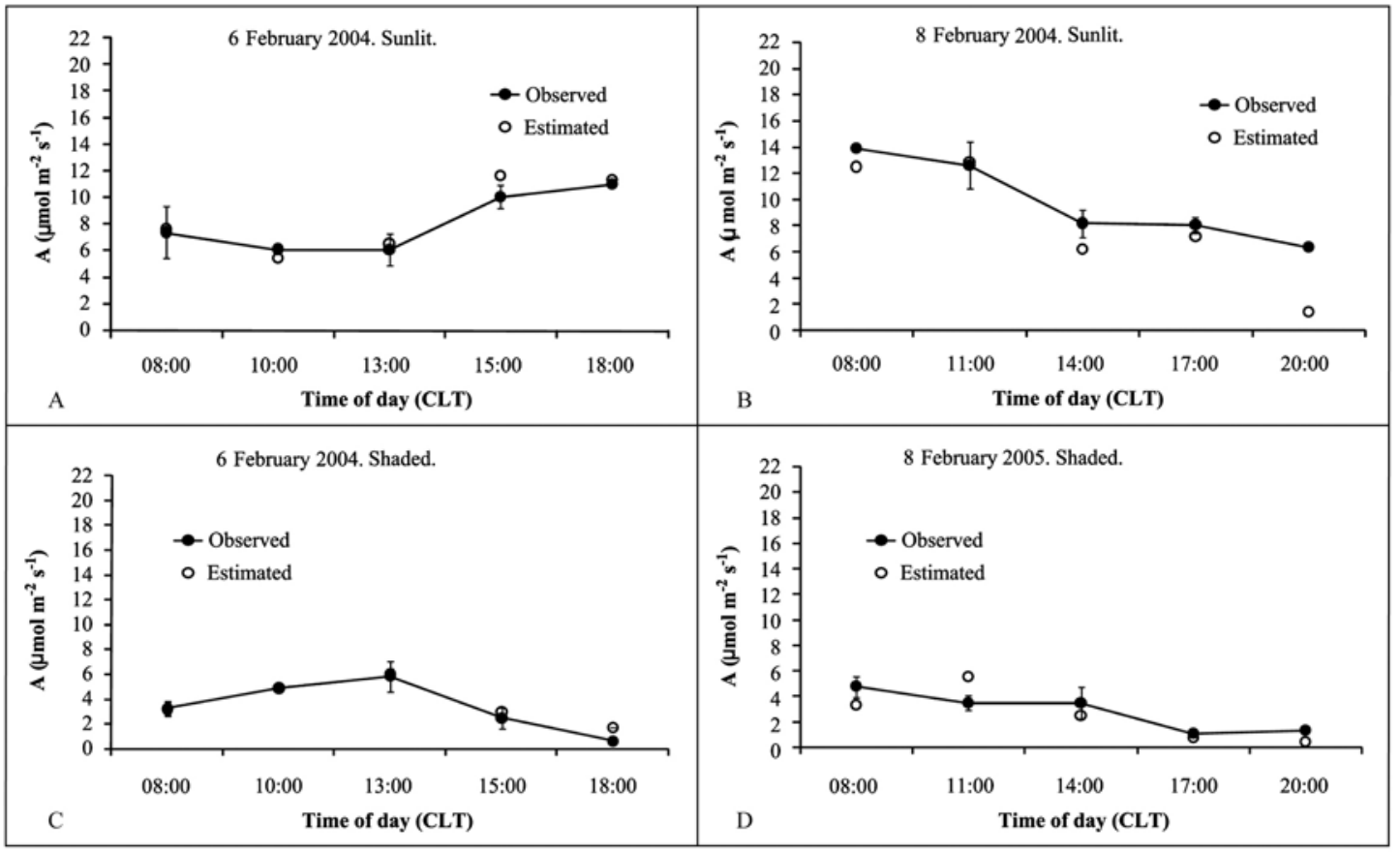

Figure 4. Daytime variation of net assimilation $(A)$ of sunlit and shaded leaves for one day each season: 6 February 2004 (A and C) and 8 February 2005 (B and D). Each point represents average of three replicates. Cabernet Sauvignon grapevines, Pencahue, Maule Region, Chile. Vertical bars represent mean standard error. CLT: Chilean local standard time. 


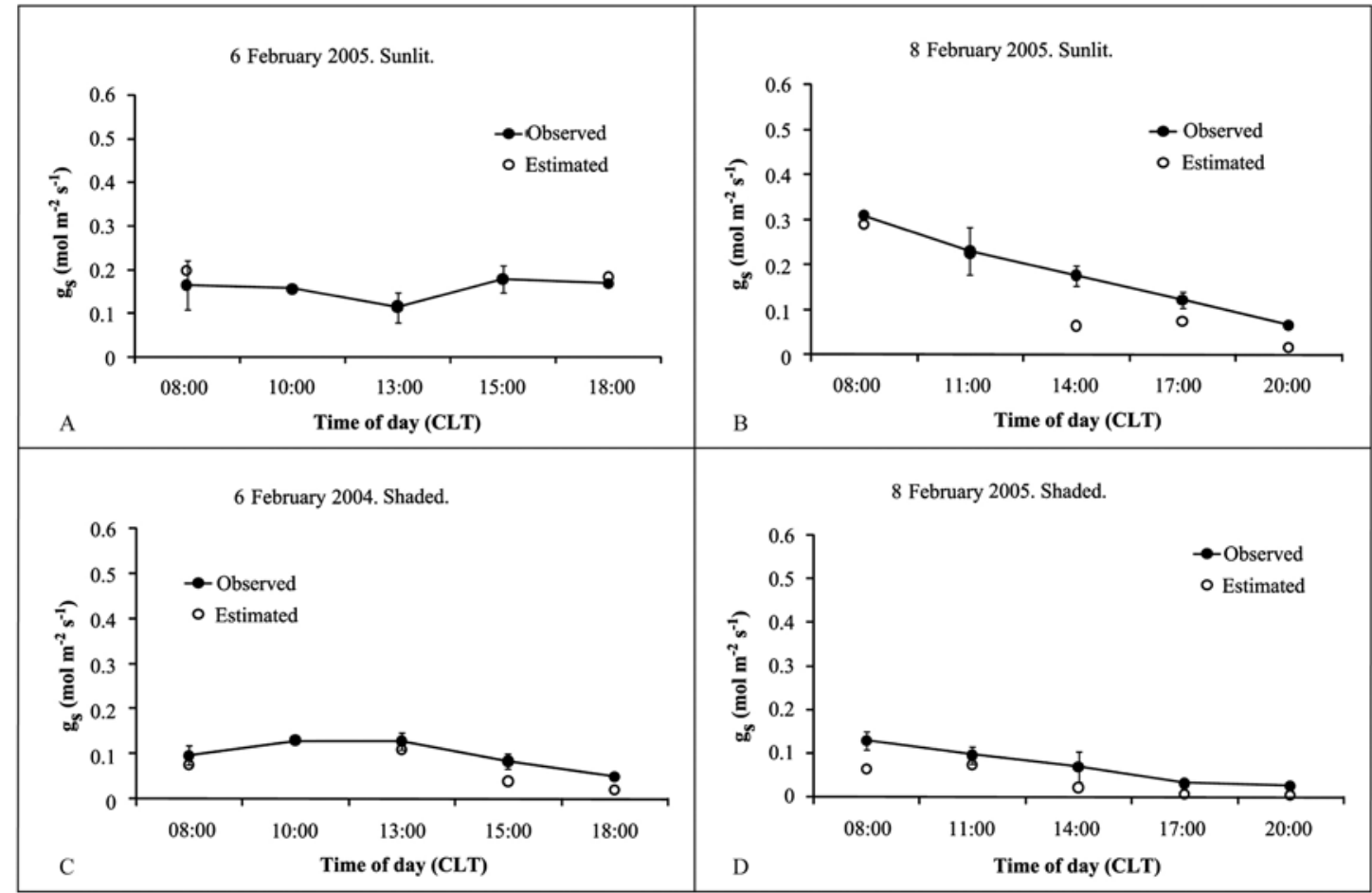

Figure 5. Daytime variation of stomatal conductance ( $g_{s}$ ) of sunlit and shaded leaves for one day each season: 6 February 2004 (A and C) and 8 February 2005 (B and D). Each point represents average of three replicates. Cabernet Sauvignon grapevines, Pencahue, Maule Region, Chile. Vertical bars represent mean standard error. CLT: Chilean local standard time.

\section{RESUMEN}

Validación de un modelo para estimar la conductancia estomática de hojas en vides cv. Cabernet Sauvignon. El modelo acoplado de asimilación neta y conductancia estomática $\left(A-g_{s}\right)$ fue evaluado para estimar la conductancia estomática de hojas $\left(g_{s}\right)$ de un viñedo regado por goteo (Vitis vinifera L. cv. Cabernet Sauvignon)

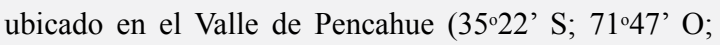
150 m.s.n.m.), Región del Maule, Chile, durante las temporadas 2003-2004 y 2004-2005. Además, se realizó una calibración de la conductancia del mesófilo $\left(g_{m}\right)$, valor máximo de humedad específica a saturación $\left(D_{\max }\right)$ y el factor acoplado $\left(f_{0}\right)$ en vides creciendo en maceteros de 35 L. Para calibrar y evaluar el modelo $A$ - $g_{s}$ se utilizó un analizador infrarrojo de gases, el cual permitió medir simultáneamente la asimilación neta $(A)$ y la conductancia estomática $\left(g_{s}\right)$ en intervalos de tiempo de 2 a $3 \mathrm{~h}$. La calibración indicó que los valores de $g_{m}, D_{\max }$ y $f_{0}$ fueron de $1,15 \mathrm{~mm} \mathrm{~s}^{-1} ; 52,31 \mathrm{~g} \mathrm{~kg}^{-1}$ y 0,90 respectivamente. La validación en el viñedo regado por goteo mostró que el modelo $A-g_{s}$ fue capaz de estimar la conductancia estomática con una raíz del cuadrado medio del error (RMSE) de $0,05 \mathrm{~mol} \mathrm{~m}^{-2} \mathrm{~s}^{-1}$, una eficiencia del modelo de $61 \%$ y un índice de acuerdo de $90 \%$. El análisis de sensibilidad indicó que el modelo es considerablemente afectado por la parametrización de $g_{m}, D_{\max } \mathrm{y} f_{0}$.

Palabras clave: modelo $A-g_{s}$, fotosíntesis, conductancia del mesófilo, potencial hídrico del xilema, análisis de sensibilidad.

\section{LITERATURE CITED}

Acevedo, C., S. Ortega-Farías, C. Hidalgo, Y. Moreno, y F. Córdova. 2005. Efecto de diferentes niveles de agua aplicada en poscuaja y pospinta sobre la calidad del vino cv. Cabernet Sauvignon. Agric. Téc. (Chile) 6:397-410.

Baldocchi, D.D., R.J. Luxmoore, and J.L. Hatfield. 1991. Discerning the forest from the trees: an essay on scaling canopy stomatal conductance. Agric. For. Meteorol. 54:197-226.

Calvet, J.-C. 2000. Investigating soil and atmospheric plant water stress using physiological and micrometeorological data. Agric. For. Meteorol. 103:229-247. 
Calvet, J.-C., J. Noilhan, and P. Bessemoulin. 1998a. Retrieving the root-zone soil moisture from surface soil moisture or temperature estimates: a feasibility study based on field measurements. J. Appl. Meteorol. 37:371-386.

Calvet, J.-C., J. Noilhan, J.-L. Roujean, P. Bessemoulin, M. Cabelguenne, A. Olioso, and J.-P. Wigneron. 1998b. An interactive vegetation SVAT model tested against data from six contrasting sites. Agric. For. Meteorol. 92:73-95.

Calvet, J.-C., V. Rivalland, C. Picon-Cochard, and J.-M. Guehl. 2004. Modeling forest transpiration and $\mathrm{CO}_{2}$ fluxes-response to soil moisture stress. Agric. For. Meteorol. 124:143-156.

Choné, X., C. Van Leeuwen, D. Dubourdieu, and J.P. Gaudillère. 2001. Stem water potential is a sensitive indicator of grapevine water status. Ann. Bot. (London) 87:477-483.

Collatz, G.J., J.T. Ball, C. Grivet, and J.A. Berry. 1991. Physiological and environmental regulation of stomatal conductance, photosynthesis and transpiration: a model that includes a laminar boundary layer. Agric. For. Meteorol. 54:107-136.

Düring, H. 2003. Stomatal and mesophyll conductances control $\mathrm{CO}_{2}$ transfer to chloroplasts in leaves of grapevine (Vitis vinifera L.). Vitis 42:65-68.

Farquhar, G.D., S. von Caemmerer, and J.A. Berry. 1980. A biochemical model of photosynthetic $\mathrm{CO}_{2}$ assimilation in leaves of $\mathrm{C}_{3}$ species. Planta 149:78-90.

Garnier, P., C. Néel, B. Mary, and F. Lafolie. 2001. Evaluation of a nitrogen transport and transformation model in bare soil. Eur. J. Soil Sci. 52:253-268.

Jacobs, C.M.J. 1994. Direct impact of atmospheric $\mathrm{CO}_{2}$ enrichment on regional transpiration. 179 p. Ph.D. Thesis. Agricultural University, Wageningen, The Netherlands.

Jacobs, C.M.J., B.J.J.M. van den Hurk, and H.A.R. de Bruin. 1996. Stomatal behaviour and photosynthetic rate of unstressed grapevines in semi-arid conditions. Agric. For. Meteorol. 80:111-134.

Jarvis, P.G. 1976. The interpretation of the variations in leaf water potential and stomatal conductance found in canopy in the field. Phil. Trans. Roy. Soc. Lond. B. 273:593-610.

Mayer, D.G., and D.G. Butler. 1993. Statistical validation. Ecol. Model. 68:21-32.
Moutinho-Pereira, J.M., C.M. Correia, B.M. Gonçalves, E.A. Bacelar, and J.M. Torres-Pereira. 2004. Leaf gas exchange and water relations of grapevines grown in three different conditions. Photosynthetica 42:81-86.

Olioso, A., S. Ortega-Farías, H. Valdés, y R. Antonioletti. 2005. Estimación de la evapotranspiración en tomate usando el modelo de interacción suelo-vegetaciónatmósfera (ISBA). Agric. Téc. (Chile) 65:284-294.

Ortega-Farias, S., M. Carrasco, A. Olioso, C. Acevedo, and C. Poblete. 2007. Latent heat flux over a Cabernet Sauvignon vineyard using the Shuttleworth and Wallace model. Irrig. Sci. 25:161-170.

Ortega-Farías, S., A. Olioso, R. Antonioletti, and N. Brisson. 2004. Evaluation of the Penman-Monteith model for estimating soybean evapotranspiration. Irrig. Sci. 23:1-9.

Patakas, A., G. Kofidis, and A.M. Bosabalidis. 2003. The relationships between $\mathrm{CO}_{2}$ transfer mesophyll resistance and photosynthetic efficiency in grapevine cultivars. Sci. Hortic. (Canterbury, Engl.) 97:255263.

Pire, R., and M. Ojeda. 1999. Effects of the irrigation regime on water relations of a table grape and two wine grape cultivars in a semiarid region of Venezuela. Acta Hort. (ISHS) 493:97-102.

Sibille, I., H. Ojeda, J. Prieto, S. Maldonado, J.N. Lacapere, and A. Carbonneau. 2007. Relation between the values of three pressure chamber modalities (midday leaf, midday stem and predawn water potential) of 4 grapevine cultivars in drought situation of the southern of France. Applications for the irrigation control. p. 685-695. In Proceeding of the $\mathrm{XV}^{\text {th }}$ Conference of Groupe d'Etude des Systèmes de Conduite de la Vigne (GESCO), Porec, Croacie. 20-23 June 2007.

Singsaas, E.L., D.R. Ort, and E.H. DeLucia. 2003. Elevated $\mathrm{CO}_{2}$ effects on mesophyll conductance and its consequences for interpreting photosynthetic physiology. Plant Cell Environ. 27:41-50.

Thornley, J.H.M., and I.R. Johnson. 2000. Plant and crop modelling: A mathematical approach to plant and crop physiology. 669 p. The Blackburn Press, Caldwell, New Jersey, USA.

Willmott, C.J. 1982. Some comments on the evaluation of model performance. Bull. Am. Meteorol. Soc. 63:1309-1313. 